\title{
Pan̂cādhikaraṇa, a Sāṃkhya teacher
}

\section{Megumu Honda}

The Yuktidīpik $\overline{\mathbf{a}}^{1)}$ presents to us a new parampară of Sāmphya teachers;

-Hārīta-Vārddhali-Kairāta-Paurikā-Rṣabheśvara - Pan̂cādhikaraṇa - PatañjaliVārṣagaṇya-Kauṇ ḍinya-Mūkāa-'dika….. (p. 145)

They have 'been unknown ${ }^{2}$ ) to us except for Vārșaganya. Among the teachers unknown till then Pan̂aadhikarana, as far as can be observed, is the most important and his fragments are preserved most. Followings are tentative translations of the fragments which came to my attention.

[sense organs \& instruments]

1) "bhautikān̄̄ 'ndriyān̄̄" 'ti Pan̂cādhikaraṇa-matam. (p. 91)

"the sense organs consist of matters."

2) “daśa-vidham” iti Tāntrikāḥ Pan̂cādhikaraṇa-prabhṛtayaḥ. (p. 112)

"ten-fold ${ }^{3)}$ (is instruments)."

3) “(karaṇānām mahtĩ svabhãvā-'tivṛttị̣ pradhānāt,) sarvā parata” iti Pan̂cādhikaraṇah. (p. 91)

"(the faculty of instruments surpasses by its nature the Primary Matter, and) all (of their faculties) come from others (i. e. objects)."4)

[knowledge]

4) “Karaṇaṃ nirlikhita-svarūpaṃ śūnya-grāma-nadī-kalpam. prākṛta-vaikṛtikāni tu jn̂ānāni prerakā-'nga-saṃgṛhītāni pradhānād āgacchanti ce" 'ti Pan̄cādhikaraṇah. (p. 91)

"the instrument is of nature (easily) to be scratched, like a vacant village

1) Ed. by R. C. Pandeya 1967, Delhi, the pages of which present author cites. Formerly ed. by P. Chakravarti, Calcutta 1938.

2) Patanjali does not seem to be identical with the author of the Yoga Sutra, cf. S. Takagi; The Early teachers of Sämkhya and Their Thoughts, JIBS. vol. X. no.

1. pp. $74 \sim 5$.

3) Cf. SK. $25 \& 32$.

4) Cf. SK. 31. 
or an empty river. But the innate and the acquired knowledges are received by the limbs of director (buddhi ?)5) and arrive at the Primary Matter."

5) yaḥ Pan̂cādhikaraṇa-pakṣaḥ "prākṛta-vaikṛtānāṃ jn̂ānānāṃ pradhāna-vac chuṣka-nadī-sthānīyā-'ntaḥkaraṇe bāhye ca preraka-jn̄ānā-'mśaka-kṛta upanipātaḥ, tathā sāttvika-sthity-ātma-kṛtam apratyayasyā 'vasthānam" iti. (p. 96) "the innate and the acquired knowledges occur as being made to be a portion of the director's knowledge on both inner and outer instruments together with the Primary Matter which are (, as it were,) in the state of a dried up river. Likewise (the maintenance that a knowledge is) made to be of the steady nature of sattva is the stand-point of a diffident one."

6) Pan̂cādhikaraṇasya tāvat "dvividhaṃ jn̂ānam prākṛtikam vaikṛtikạ̣ ca. prākṛtikạ̣ trividham— tattva-sama-kālaṃ sāṃsiddhikam ābhișyandikạ̣ ca. tatra tattva-sama-kālaṃ saṃhata's ca mahāṃs tattvā-'tmanā mahati pratyayo bhavati. utpanna-kārya-kāraṇasya tu sāṃsiddhikam ābhiṣyandikam ca bhavati. sāṃ-siddhikaṃ yat saṃhata-vyūha-sama-kālaṃ niṣpadyate, yathā paramarṣer jn̂ā-nam. ābhiṣyandikam ca saṃsiddha-kārya-kāranasya kāraṇā-'ntareno 'tpadyate. vaikṛtam tu dvividham sva-vaikṛtam para-vaikṛtam ca. sva-vaikṛtam tārakam. paravaikṛtam siddhy-antarāṇi. āha ca-

tattva-samaṃ vaivartạ̣, tatrā 'bhiṣyandikam dvitīyaṃ syāt, vaikṛtam atas tṛtīyam șāț-kauśikam etad ākhyātam.

atra tu tattvaiḥ saho 'tpatty-aviśeșāt sāṃsiddhikam abhedenā 'ha-

vaikṛtam api ca dvividham, sva-vaikṛtam tatra tārakaṃ bhavati, syāt sapta-vidhaṃ para-vaikṛtam svatārā-'di nirdișțam.

iti. yathā jn̂anam evam dharmā-'dayo 'pī' 'ti. (p. 123) "knowledge is two-fold, viz. innate and acquired. (Again) the innate (knowledge) is three-fold, viz. 1) simultaneous with the principles, 2) spontaneous and 3) surplus. Among them, 1) the simultaneous with the principles means that (when) the Great (is) accumulated (it) becomes a conception in the Great as the nature of this principle. 2) On the other hand the one who has produced the effect from the cause ${ }^{6}$ ) has the spontaneous and the surplus.

5) buddhau prayacchanti (SK. 36). 
The spontaneous is effected simultaneously with the orderly arrangement of forming one's body, such as the knowledge of a great sage. 3) The surplus is produced by other cause to the one who has fully attained the effect from the cause ${ }^{6}$. On the other hand the acquired is two-fold, viz. 1) the acquired by himself and 2) the acquired by others. 1) The acquired by himself is $t_{a} r a k a^{7}$ ), and 2) the acquired by others are the other accomplishments ${ }^{7}$. And (the following is) said.

'The simultaneous with the principles is revolving, (and) among them the surplus will be the second, then the spontaneous (will be) the third which is called the one made of six sheaths. ${ }^{\text {'8) }}$

On this point, however, he told the spontaneous as identical because it is not different (from the simultaneous) in point of being produced together with the principles.

'The acquired is two-fold too, which is declared (as follows). Among them the acquired by himself is täraka, (and) the acquired by others are seven, viz. svatāra ${ }^{9)}$ and so forth.'

As the knowledge so are the good and others, too." [body]

7) Pañcādhikaraṇasya tāvad "vaivartam śarīraṃ mātā-pitṛ-samsarga-kāle karaṇā-'vișṭam śukra-śoṇitam anupraviśati. tad anupraveśāc ca kalalā-'di-bhāvena vivardhate. vyūẹhā-'vayavam tū 'palabdha-pratyayaṃ mātur udarān nisșrtya yan dharmā-'dharman șaṭ-siddhy-upabhoga-kāle kṛtau tad-vaśād avatișthate. yāvat tat-kṣayāc charīra-pātas tāvat. yadi dharma-saṃș̣taṃ karaṇaṃ tato dyu-deśaṃ sūkṣma-śarīrena prāpyate, tad-viparyayāt tu yātanā-sthānaṃ tiryag-yonim vā, miśrībhāvena mānuṣyam. evam ātivāhikaṃ sūkṣam-śarīram indriyānāṃ dhāraṇa-prāpaṇa-samārtham nityam bāhyenā 'pāyinā pariveștyate parityajyate ca." (p. 121)

6) This seems to mean the one who has corpareity.

7) Cf. coms on SK. 51; Yoga Sūtra III. 54

8) șățkauśika; rudhira (blood), māṃsa (flesh), snāyu (sinew), śukra (semen), asthi (bone), majjan (marrow). Cf. coms. ad SK 39 \& Yogabhāṣya III. 29.

9) sutära ( $k a)$, according to the coms on SK 51 etc. 
"The revolving body, when mother and father have union, has reached the organ and then enters into sperm and flood. And having entered into them the (revolving body) increases in a state of embryo and others. Further having developed its limbs and obtained the consciousness the (body) goes out from mother's belly and exists by force of the good and the evil made in the time when it experiences the six accomplishments ${ }^{10}$. It lasts until the down-fall of the body due to the destruction of these (goods and evils). If the organ wanders towards the good, then it attains the celestial place in (the form of) subtle body. On the contrary (it attains) the place of torment or animals due to the reversed (i. e. the evil), (and it attains) the human (nature) due to the mixture. Thus the transmigrating subtle body is capable of holding and leading the organs, is eternal, is wrapped and is abandoned by perishable external (objects)."11)

Pan̂cādhikarana, according to the paramparā in the Yuktidipikāa, is a predecessor of the teacher of Vārṣaganya who certainly is earlier than the Mahābhārata and Nāgārjuna ${ }^{12)}$ (A. D. 150 ca.). He is said to belong to Tantra school (frag. 2), though he maintains that the sense organ consists of matters (frag. 1) like Yoga school ${ }^{13)}$. The instruments (karana) are ten according to his assertion (frag. 2). Does he disapprove the manas, ahainkära and buddhi as instruments? No, he mentions antahkarane bāhye ca in his fragment 5 . He might hold the sense organs (indriya) to be ten-fold, not the instrument ( $k a$ rana) as the Yuktidipikā seems to report, though he disagrees with İśvarakṛ̣ṇa who counts organs to be eleven (SK. 25). preraka in fagments 4 and 5 alludes

10) șaț-siddhi, not mentioned in other Sāṃkhya texts!

11) Cf. SK.39.

12) Nāgārjuna refers to Vārṣagaṇya in his commentary on the Daśabhūmika-sũtra (Taisho. vol. XXVI. p. 31c).

13) "That the sense organs consist of matter is of Yoga (school), and that the sense organs do not consists of matter is of Sāmkhya (school)." (Nyāyavārttika ad NS I. 1. 29). The Yoga Sūtra, however, does not remark distinctly this view. In contrast with this fact Nyāya school is said to assert this view according to the commentary on the Sāmkhya Sūtra II. 20 . 
for certain to buddhi, the producer of karana, or to theP rimary Matter (pradhãna) with some possibility. The agent of metempsychosis consists mainly of karana (frag. 7).

Each of $j \tilde{n} \bar{a} n a$ etc. is considered to have two stages and five subdivisions as follows;

$$
\text { bhāva }\left\{\begin{array}{l}
\text { prākṛtika }\left\{\begin{array}{l}
\text { tattva-sama-kāla } \\
\text { sāṃsiddhika } \\
\bar{a} \text { ăbhị̣yandika }
\end{array}\right. \\
\text { vaikṛtika }\left\{\begin{array}{l}
\text { sva-vaikṛtika; tāraka } \\
\text { para-vaikṛtika; svatāra, etc. }
\end{array}\right.
\end{array}\right.
$$

Three older commentaries on the Sāṃkhyakārikā; 金七十論, Gauḍapāda and Māțhara, divide pratyaya-sarga into parallel three, sāṃsiddhika, prākṛtika and vaikṛtika, which are changed into two by Pan̂cādhikaraṇa who is sucdeeded by Vācaspatimiśra in his Sāmphyatattvakaumudī. Explanation on body (frag. 7) agrees on the whole with that of the coms on SK 39.

In sum Pan̂aādhikarana does not seem to have an assertion quite different from so-called classical Sāṃkhya, though being somewhat Yogaic in a view on the materials of organ and unique in six siddhi doctrine.

New Publication

Advaita of Śankara; A Reappraisal

Impact of Buddhism and Sāmkhya

on Śanikara's Thought

by S. G. Mudgal

Delhi, 1975. 